\title{
Development of Moisture Stress Tolerant Brinjal cv. Utkal Anushree (Solanum melongena L.) Using Agrobacterium Mediated Gene Transformation
}

\author{
Deepti B. Sagare ${ }^{1} \&$ I. C. Mohanty ${ }^{1}$ \\ ${ }^{1}$ Department of Agricultural Biotechnology, College of Agriculture, Bhubaneswar, Odisha, India \\ Correspondence: I. C. Mohanty, Department of Agricultural Biotechnology, College of Agriculture, OUAT, \\ Bhubaneswar 751003, Odisha, India. E-mail: icmohanty1@rediffmail.com
}

\author{
Received: May 2, 2012 Accepted: May 21, 2012 Online Published: July 11, 2012 \\ doi:10.5539/jas.v4n8p141 \\ URL: http://dx.doi.org/10.5539/jas.v4n8p141
}

\begin{abstract}
An efficient and reproducible in vitro regeneration protocol was developed with high frequency regeneration of shoot buds from shoot-tip in MS medium + BAP $(2.0 \mathrm{mg} / \mathrm{l})$ in Brinjal cv. Utkal Anushree. Rooting was obtained on MS medium+ NAA (0.01 mg/l). The Agrobacterium tumefaciens strain GV3107 containing a binary vector pCAMBIA2300 carrying rd29A::DREB1A gene has been used for transformation. The shoot-tip from in vitro grown seedling was pre-cultured for $72 \mathrm{hrs}$ and co-cultivated for $24 \mathrm{hrs}$. Shoot buds were produced on the regeneration medium containing kanamycin $(100 \mathrm{mg} / \mathrm{l})$ and cefotaxime $(250 \mathrm{mg} / \mathrm{l})$. A transformation frequency of $6.40 \%$ was achieved after PCR analysis with gene specific primer. The gene expression for moisture stress tolerance was assessed through morpho-physiological and biochemical analyses.
\end{abstract}

Keywords: Solanum melongena, in vitro regeneration, genetic transformation, Agrobacterium tumefaciens, Drebla

\section{Introduction}

Brinjal (Solanum melongena L. 2n=24; Family-Solanaceae) is an agronomically important non-tuberous, solanaceous crop of sub-tropics and tropics. Brinjal (eggplant) is one of the important solanaceous vegetable crop which contains $92.7 \%$ moisture, $1.4 \%$ protein, $1.3 \%$ fibres, $0.3 \%$ fat, $0.3 \%$ minerals and the remaining $4 \%$ consists of various carbohydrates and vitamins (A and C). Brinjal cultivation in India is estimated to cover about $8.14 \%$ vegetable area with a contribution of $9 \%$ to total vegetable production. Abiotic stress is the primary cause of crop loss worldwide, reducing average yields for most major crop plants by more than 50\% (Mayra Rodriguez et al., 2005). Major breakthrough in abiotic stress technology comes when the DREB/CBF genes from Arabidopsis thaliana and some other plants were identified. The DREB1A/CBF3 genes, encode transcriptional activators that control the expression of genes containing C-repeat/Dehydration responsive element (DRE) (regulatory element in their promoters) (Liu et al., 1998). Constitutive expression of CBF3/DREB1A in transgenic Arabidopsis plants has been shown to induce the expression of several genes related to abiotic stress. But overexpression of DREB1A/CBF3 also causes severe growth retardation (Dwarf phenotype) under normal growth conditions. Use of stress inducible promoter rd29A instead of the constitutive CaMV35S promoter for overexpression of DREB1A/CBF3 minimizes the negative effect on plant growth (Yamaguchi-Shinozaki et al., 1993; Kasuga et al., 1999). The present investigation has been carried out with an objective of incorporating moisture stress tolerance (rd29A::DREB1A gene) in locally adopted high yielding cultivar following Agrobacterium mediated transformation.

\section{Materials and Methods}

\subsection{The Materials}

The high yielding Brinjal cv. Utkal Anushree sensitive to moisture stress was taken for genetic transformation with rd29A::DREB1A gene for moisture stress tolerance. Agrobacterium strain GV3107 harboring pCAMBIA2300 which contains the gene construct (IARI, New Delhi) was cultured in YEMA medium containing kanamycin (50 $\mathrm{mg} / \mathrm{l})$ and rifampicin $(10 \mathrm{mg} / \mathrm{l})$. Two different explants namely shoot-tip and hypocotyl and the basal MS medium with various concentrations of phytohormones (BAP, kinetin, NAA) were used for organogenesis. Growth inhibition of normal plant was studied by taking different concentrations of kanamycin (20-100 mg/l) in the background of regeneration medium for developing selection method of putative transformants. 


\subsection{Co-cultivation}

It was carried out following Koivu et al., 1995 for solanaceous crops with modifications. Shoot tip explants were taken from 25 days old in vitro grown seedlings and co-cultivated with Agrobacterium. The overnight grown culture was centrifuged at $10,000 \mathrm{rpm}$ for 5 minutes at $22^{\circ} \mathrm{C}$, the supernatant was discarded and the bacterial pellet was suspended in liquid AB medium. Shoot tips were suspended in Agrobacterium suspension and kept for 5 minutes with gentle shaking. Excess bacteria were blot dried and explants were placed in petriplate lined with blotting paper which was wet by liquid plant growth medium (LPGM). Plate was wrapped with aluminium foil to avoid the drying of blotting paper due to evaporation of LPGM medium and kept for 2 days in culture room for co-cultivation. Then the explants were washed with sterile distilled water having cefotaxime (500 mg/l), blot dried and inoculated on the MS+2.0mg/l BAP $+250 \mathrm{mg} / 1$ cefotaxime $+100 \mathrm{mg} / \mathrm{l}$ kanamycin medium.

\subsection{Isolation of Plasmid DNA}

Plasmid DNA containing the gene construct was isolated from Agrobacterium by alkali lysis method (Sambrook and Russell, 2001). A single Agrobacterium colony was picked up aseptically using a sterile inoculation needle and was grown overnight in $10 \mathrm{ml}$ YEMA medium containing kanamycin $(50 \mathrm{mg} / \mathrm{l})$, gentamycin $(10 \mathrm{mg} / \mathrm{l})$ and rifampicin $(10 \mathrm{mg} / \mathrm{l})$ in a sterile conical flask. Overnight grown culture was transferred to centrifuge tube and centrifuged for $15 \mathrm{~min}$ at 10,000 rpm. The supernatant was removed and cell pellet was dried to which $200 \mu \mathrm{l}$ ice cold suspension buffer was added and pellet was dissolved by vortexing. Freshly prepared lysis buffer $(200 \mu \mathrm{l})$ was added, and stored in ice. After $5 \mathrm{~min} 200 \mu \mathrm{l}$ of $1.5 \mathrm{M} \mathrm{K}$-acetate was added and mixed well (not by vortexing) and stored in ice for 10 minutes. Lysate was centrifuged for $15 \mathrm{~min}$ at $12,000 \mathrm{rpm}$. Supernatant was transferred to next tube. Equal volume of phenol-chloroform was added, vortexed and centrifuged for $10 \mathrm{~min}$ at 10,000 rpm. Aqueous upper layer was transferred to a fresh tube. DNA was precipitated by adding $600 \mu \mathrm{l}$ of isopropanol and kept at $-20^{\circ} \mathrm{C}$ temperature for overnight. Suspension was centrifuged at $12,000 \mathrm{rpm}$ for $15 \mathrm{~min}$ and DNA pellet was dried. Pellet was washed with $1 \mathrm{ml}$ of 70 percent ethanol and pellet was dried completely. The pellet was dissolved in 30 $\mu \mathrm{l}$ of $\mathrm{T}_{10} \mathrm{E}_{1}$ buffer. Then $2 \mu \mathrm{l}$ of RNAse was added and incubated at $37^{\circ} \mathrm{C}$ for $1 \mathrm{hr}$. Purified sample was stored at $-20^{\circ} \mathrm{C}$ temperature for further use.

\subsection{Isolation of Plant Genomic DNA}

Genomic DNA from putative transformants and control plants was isolated following Edwards et al., 1991. Plant tissue was macerated in pestle and mortar at room temperature without buffer for $15 \mathrm{sec}$. Extraction buffer (Tris $\mathrm{HCl}(\mathrm{pH} 7.5)-200 \mathrm{mM}, \mathrm{NaCl}-250 \mathrm{mM}$, EDTA - $2.5 \mathrm{mM}$, SDS - 0.5\%) was added to powdered plant tissues, vertexed and centrifuged at 13,000 rpm for 1 minute and $300 \mu \mathrm{l}$ supernatant was transferred to fresh eppendorf's tube. Supernatant was mixed with $300 \mu \mathrm{l}$ isopropanol and incubated at room temperature for 2 minutes and again centrifuged at 13,000 rpm for $2 \mathrm{~min}$. Pellet was dried and suspended in $100 \mu \mathrm{l} 1 \mathrm{X} \mathrm{T}_{10} \mathrm{E}_{1}$ to which $100 \mu \mathrm{l}$ Rase (1 $\mathrm{mg} / \mathrm{ml}$ ) was added and incubated at $37^{\circ} \mathrm{C}$ in water bath for half an hour. DNA was precipitated using $1 / 10^{\text {th }}$ volume of $3 \mathrm{M} \mathrm{Na}$-acetate and ethanol and incubated over night at $4^{\circ} \mathrm{C}$. The solution was centrifuged at 13,000 rpm for 2 min and pellet was dried again and was suspended in $50 \mu \mathrm{l} 1 \mathrm{X} \mathrm{T}_{10} \mathrm{E}_{1}$.

\subsection{Molecular Analysis}

The detection of transgene was carried out following PCR (AB Systems, Perkin Elmer) analysis using gene specific primer (Forward:5'TGATTATATTCCGACGCTTG3', reverse: 5'TTCATGATTATGATTCCACT3') with plasmid DNA as the positive control. PCR reaction (Template DNA-50 ng, Primer-20 ng, dNTPs - $0.1 \mathrm{mM}$, Taq DNA polymerase - $0.33 \mu \mathrm{l}$ (1 unit) and Taq assay buffer- $1 \mathrm{x}$ for $25 \mu \mathrm{l}$ reaction mix) was carried out with pre-denaturation $\left(92^{\circ} \mathrm{C}\right.$ for $\left.5 \mathrm{~min}\right), 35$ cycles of denaturation $\left(92^{\circ} \mathrm{C}\right.$ for $\left.2 \mathrm{~min}\right)$, annealing $\left(51^{\circ} \mathrm{C}\right.$ for $\left.1 \mathrm{~min}\right)$ and extension $\left(72{ }^{\circ} \mathrm{C}\right.$ for $\left.2 \mathrm{~min}\right)$ followed by general extension at $72^{\circ} \mathrm{C}$ for $10 \mathrm{~min}$. The PCR amplified products were separated on $1.2 \%$ agarose gel electrophoresis followed by gel documentation.

\subsection{Physio-biochemical Analysis}

Various growth parameters like plant height, no. of flowers and no. of leaves of control and transformed plants were recorded after 8 days' of moisture stress. Besides, the response of moisture stress was assessed in terms of Relative Water Content (RWC), Chlorophyll (Chl a \& b), Carotenoid content, Membrane Stability Index (MSI) and Proline content for gene expression studies.

\subsubsection{Relative Water Content (RWC)}

After 8 days' of moisture stress relative water content of control and transformed plant was measured following the method described by Barrs and Weatherley (1962). Leaf discs collected from control and transformed plants in replicates were saturated in distilled water in covered petriplates after taking fresh weight. These petriplates were kept at room temperature for overnight to attain turgidity. Turgid weight (Tw) of the samples was recorded after 
the blot dry of leaves. The same leaf samples were then oven dried for $48 \mathrm{hrs}$ at $80^{\circ} \mathrm{C}$ in hot air oven. Dry weight (DW) of the respective samples was recorded. RWC (\%) was determined by $\{(\mathrm{Fw}-\mathrm{Tw}) /(\mathrm{Tw}-\mathrm{Dw})\} \times 100$

\subsubsection{Estimation of Photosynthetic Pigments}

Photosynthetic pigments were estimated from transformed and control plants by using Acetone method of Arnon (1949) and carotenoid following Kirk and Allen (1965). Leaf sample (100 mg) was taken and crushed with sterile sand in $2 \mathrm{ml}$ of $80 \%$ acetone with the help of mortar and pestle. Extracted samples were centrifuged at 10,000 rpm for $10 \mathrm{~min}$. at $4^{\circ} \mathrm{c}$ in a refrigerated centrifuge. Supernatant was collected in fresh sterile centrifuge tube and the volume was made up to $2 \mathrm{ml}$ with $80 \%$ acetone and was kept in a dark. Absorbance was recorded at $663 \mathrm{~nm}, 645$ $\mathrm{nm}$ and $470 \mathrm{~nm}$ spectrum of wave length using UV-VIS spectrophotometer. The amount of photosynthetic pigment was calculated by using the formulae: Chla $(\mu \mathrm{g} / \mathrm{ml})=\left(12.25 \times \mathrm{A}_{663}\right)-\left(2.79 \times \mathrm{A}_{645}\right) ; C h l \mathrm{~b}(\mu \mathrm{g} / \mathrm{ml})=$ $\left(21.5 \times \mathrm{A}_{645}\right)-\left(5.1 \times \mathrm{A}_{663}\right)$ and $C h l \mathrm{a}+C h l \mathrm{~b}(\mu \mathrm{g} / \mathrm{ml})=\left(7.15 \times \mathrm{A}_{663}\right)+\left(18.73 \times \mathrm{A}_{645}\right)$. Carotenoid $(\mu \mathrm{g} / \mathrm{ml})$ was calculated as $[(1000 \times \mathrm{A} 470)-(1.82 \times C h l \mathrm{a}(\mu \mathrm{g} / \mathrm{ml}))-(85.2 \times C h l \mathrm{a}(\mu \mathrm{g} / \mathrm{ml}))] / 198$.

\subsubsection{Estimation of Proline}

The Proline content was determined according to the methods of Bates et al. (1973). As per this method, $100 \mathrm{mg}$ of leaf sample was taken and homogenized in 3\% sulfosalicylic acid. The homogenate was filtered through whatmann no. 1 filter paper and $2 \mathrm{ml}$ of filtrate was taken with $2 \mathrm{ml}$ of ninhydrin solution and $2 \mathrm{ml}$ of glacial acetic acid to make the final volume of $6 \mathrm{ml}$. The mix. was incubated at $100^{\circ} \mathrm{C}$ in heating waterbath for $1 \mathrm{hr}$. The reaction was stopped by putting on ice and $4 \mathrm{ml}$ of toluene was added and the mix. was shaken vigorously for 20-30 sec. The aqueous toluene layer was separated. The red colour was measured at $520 \mathrm{~nm}$ wavelength of light. The conc. of proline in each sample was calculated by plotting the absorbance against standard curve. The proline content was expressed on fresh weight basis (micromoles/gm tissue) as per the following formula : [\{ Proline $(\mu \mathrm{g} / \mathrm{ml}) \times \mathrm{ml}$ of Toluene $\} / 115.5] \times(5 /$ gram of sample $)$.

\subsubsection{Estimation of Membrane Stability Index}

The membrane stability index of control and transformed plant both under stress for 8days and non-stress was estimated following Onwueme (1979). Leaf samples (100 mg) were taken from all the above mentioned plants in replicate in the test tubes containing $10 \mathrm{ml}$ of distilled water. One set of the test tubes containing plant samples was heated at $40^{\circ} \mathrm{C}$ for $30 \mathrm{~min}$. in water bath, and the electrical conductivity of the solution was measured in the conductivity meter $(\mathrm{C} 1)$. Another set of test tubes was boiled at $100{ }^{\circ} \mathrm{C}$ on boiling water bath for $10 \mathrm{~min}$. and the electrical conductivity of the solution was measured in the conductivity meter (C2). Membrane stability index of each sample was calculated by using following formulae: Membrane stability index $=\{1-(\mathrm{C} 1 / \mathrm{C} 2)\} \times 100$.

\section{Results}

Multiple shoots arose on MS medium supplemented with BAP (1.0-2.0 mg/l) with maximum production occurring at $2.0 \mathrm{mg} / \mathrm{l} \mathrm{BAP}$ from both shoot-tip and hypocotyls explants (13 and 11.75) and took 18 and 22.75 days for the initiation of adventitious shoots respectively (Table 1) (Plate 1). Sharmin et al. (2008) also found similar higher response with shoot tip explants. The highest frequency of shoot regeneration was obtained in BAP medium (2.0 $\mathrm{mg} / \mathrm{l})$ in all the explants used. However, Kinetin gives very poor response for shoot induction. These results were in accordance with Mohinder et al., (2011) and Sharmin et al. (2008). MS medium supplemented with $0.01 \mathrm{mg} / 1$ NAA produced $95 \%$ of rooting (Table 2) (Plate 2). Hardening of in vitro regenerated plants was carried out in soil: sand: FYM (2:1:0.5) (Plate 3). Shoot growth was completely inhibited at $100 \mathrm{mg} / \mathrm{l} \mathrm{kanamycin}$ (Table 3, Plate 4). Pre-culture period of $72 \mathrm{hrs}$ prior to co-cultivation and co-cultivation period of $24 \mathrm{hrs}$ were found to be most suitable for getting maximum percentage of putative transformants (Table 4). The acetosyringone @ $200 \mathrm{mM}$ was used for effective infection of Agrobacterium leading to T-DNA transfer (Liu et al., 1990). In this study, cefotaxime at $500 \mathrm{mg} / \mathrm{l}$ was found to control subsequent growth of Agrobacterium in the cultures (Plate 5) (V. Prabhavathi et al., 2002; Franklin et al., 2003). Transformed plants were selected by kanamycin based analysis (Plate 6) and confirmed by molecular analysis of transgene. Kanamycin based selection system revealed a transformation frequency of $9.20 \%$ which was further reduced to $6.40 \%$ following molecular analysis by PCR amplification (Table 5, Plate 7). Expression of DREB1A gene was studied by morpho-physiological and biochemical analysis of control and transformed plants under moisture stress for 8 days and it was found that, there was no significant difference in the morphological characters of transformed and control plants but, the proline content, photosynthetic pigment content, relative water content were high in the transformed plants which were under moisture stress. Membrane stability index was reduced in the stressed control plant but remains approximately same for transformed plants both stressed and non-stressed along with control non-stressed (Table 6 , Figure 1). Further the stress was extended up to 15 days and it was observed that, control plants were completely dried but the transformed plants were in normal condition (Plate 8). 
Table 1. Direct Organogenesis- Effect of Explants and PGRs

\begin{tabular}{ccccccc}
\hline \multirow{2}{*}{ Treatment } & \multicolumn{2}{c}{ Hormonal combination(mg/l) } & \multicolumn{2}{c}{ Days to initiation of adventitious shoots } & \multicolumn{2}{c}{ Avg. no. of shoots produced/tube } \\
\cline { 2 - 7 } & BAP & Kinetin & Shoot-tip & Hypocotyl & Shoot-tip & Hypocotyl \\
\hline 1 & 1.0 & - & 22.25 & 24.25 & 10.00 & 4.25 \\
2 & 1.5 & - & 19.25 & 21.25 & 12.00 & 7.50 \\
3 & $\mathbf{2 . 0}$ & - & $\mathbf{1 8 . 0 0}$ & $\mathbf{2 2 . 7 5}$ & $\mathbf{1 3 . 0 0}$ & $\mathbf{1 1 . 7 5}$ \\
4 & - & 1.0 & 22.75 & 27.5 & 2.75 & 3.00 \\
5 & - & 1.5 & 21.75 & 25.25 & 3.75 & 2.75 \\
6 & - & 2.0 & 21.5 & 25.5 & 3.25 & 3.00 \\
CD $(0.05)$ & & & 0.61 & 0.72 & 0.85 & 0.56 \\
CV\% & & & 1.95 & 1.97 & 7.57 & 7.00 \\
\hline
\end{tabular}

* 40 Explants were cultured in each treatment under four replications

Table 2. Response of shoots on different rooting media

\begin{tabular}{cccl}
\hline Response of shoots* on different rooting media & $\begin{array}{c}\text { No. of shoots } \\
\text { producing roots }\end{array}$ & $\begin{array}{c}\text { Percent } \\
\text { response }\end{array}$ & Type of roots \\
\hline MS control & 8.50 & 85.00 & Long and thin roots \\
$1 / 4^{\text {th }}$ MS & 6.00 & 60.00 & Short and thin roots \\
MS + NAA $(0.01 \mathrm{ppm})$ & 9.50 & 95.00 & Long and thick roots (multiple, adventitious) \\
MS + NAA $(0.05 \mathrm{ppm})$ & 8.75 & 87.50 & Short and thick roots(with callus at shoot cut) \\
MS + NAA $(0.1 \mathrm{ppm})$ & 8.50 & 85.00 & Short and thick roots(with callus at shoot cut) \\
$\mathrm{CD}(0.05)$ & 0.68 & & \\
$\mathrm{CV} \%$ & 5.42 & & \\
\hline
\end{tabular}

* 10 shoots were cultured in each treatment under four replications

Table 3. Kanamycin based selection system

\begin{tabular}{cccc}
\hline Sl. No. & Kanamycin concentration $(\mathrm{mg} / \mathrm{l})$ & $\begin{array}{c}\text { *Explants survival } \\
\text { after two weeks }\end{array}$ & Percent survival \\
\hline 1 & Control & 40.00 & 100 \\
2 & 20 & 39.50 & 98.75 \\
3 & 40 & 35.75 & 89.37 \\
4 & 60 & 29.25 & 73.12 \\
5 & 80 & 24.25 & 60.62 \\
6 & 100 & 0 & 0 \\
CD $(0.05)$ & & 1.51 & \\
CV\% & & 3.57 & \\
\hline
\end{tabular}

* 40 shoots were cultured in each treatment under four replications 
Table 4. Effect of pre-culture and Co-cultivation period on survivability of brinjal

\begin{tabular}{|c|c|c|c|c|c|c|c|c|c|c|}
\hline \multirow{4}{*}{ Sl. No } & \multicolumn{3}{|c|}{$\begin{array}{c}\text { Effect of pre-culture period on survival of } \\
\text { eggplant explants after co-cultivation }\end{array}$} & \multicolumn{7}{|c|}{ Effect of co-cultivation period on the explant survivability in eggplant } \\
\hline & \multirow{3}{*}{$\begin{array}{l}\text { Duration } \\
\text { (hrs) of } \\
\text { preculture }\end{array}$} & \multirow{3}{*}{$\begin{array}{l}\text { Avg. No. of } \\
\text { explants } \\
\text { survived after } \\
8 \text { days of } \\
\text { co-cultivation } \\
\text { for } 24 \text { hrs }\end{array}$} & \multirow{3}{*}{$\begin{array}{l}\text { Survival } \\
\quad(\%)\end{array}$} & \multirow{3}{*}{$\begin{array}{l}\text { Duration of } \\
\text { co-cultivation } \\
\text { (hrs) }\end{array}$} & \multicolumn{4}{|c|}{ Response after fifteen days } & \multicolumn{2}{|c|}{ Agrobacterium growth } \\
\hline & & & & & $\begin{array}{r}\text { after } 4^{\text {th }} \\
\text { was }\end{array}$ & taxime & $\begin{array}{r}\text { after } 4^{\text {th }} \\
\text { wa }\end{array}$ & enicillin & \multirow{2}{*}{$\begin{array}{c}\text { In cefotaxime } \\
\text { washed } \\
\text { culture }\end{array}$} & \multirow{2}{*}{$\begin{array}{c}\text { In } \\
\text { carbenicillin } \\
\text { washed } \\
\text { culture }\end{array}$} \\
\hline & & & & & $\begin{array}{l}\text { Explants } \\
\text { proliferating }\end{array}$ & $\begin{array}{l}\text { Survival } \\
\qquad \%)\end{array}$ & $\begin{array}{l}\text { Explants } \\
\text { proliferating }\end{array}$ & $\begin{array}{l}\text { Survival } \\
\quad(\%)\end{array}$ & & \\
\hline 1 & 0 & 22.5 & 56.25 & 24 & 14.75 & 73.75 & 15.25 & 76.25 & + & - \\
\hline 2 & 24 & 26.5 & 66.25 & 48 & 10.5 & 52.5 & 14.75 & 73.75 & +++ & + \\
\hline 3 & 48 & 28.5 & 71.25 & 72 & 7.5 & 37.5 & 10.5 & 52.5 & +++ & $+1+$ \\
\hline 4 & 72 & 30.75 & 76.87 & & & & & & & \\
\hline $\mathrm{CD}(0.05)$ & & 1.07 & & & 0.50 & & 1.04 & & & \\
\hline $\mathrm{CV} \%$ & & 2.48 & & & 2.64 & & 4.45 & & & \\
\hline
\end{tabular}

*40 explants were cultured under each treatment in four replications

- : Complete inhibition of Agrobacterium growth

+: Slight appearance of Agrobacterium growth

+++: Prominent growth of Agrobacterium

Table 5. In vitro transformation studies using rd29A::DREB1A gene

\begin{tabular}{|c|c|c|c|c|c|c|}
\hline $\begin{array}{c}\text { No. of shoots } \\
\text { Obtained after } \\
\text { co-cultivation with } \\
\text { kan }(80 \mathrm{ppm}) \text { after } 45 \\
\text { days }\end{array}$ & $\begin{array}{l}\text { No. of Kan } \\
\text { (100ppm) } \\
\text { Shoots } \\
\text { obtained } 20 \\
\text { days after } \\
\text { inoculation }\end{array}$ & $\begin{array}{l}\text { No. of plantlets } \\
\text { transferred to } \\
\text { growth } \\
\text { chamber }\end{array}$ & $\begin{array}{l}\text { No. of } \\
\text { plantlets } \\
\text { survived in } \\
\text { growth } \\
\text { chamber }\end{array}$ & $\begin{array}{l}\text { *Transformation } \\
\text { frequency }(\%) \\
\text { (based on kan } \\
\text { selection system) }\end{array}$ & $\begin{array}{c}\text { PCR } \\
+\mathrm{ve}\end{array}$ & $\begin{array}{c}* * \text { Transformation } \\
\text { frequency }(\%) \\
\text { Based on molecular } \\
\text { analysis }\end{array}$ \\
\hline 250 & 23 & 23 & 17 & 9.20 & 16 & 6.40 \\
\hline
\end{tabular}

Table 6. Morpho-physiological and biochemical analysis of transgene expression

\begin{tabular}{|c|c|c|c|c|c|}
\hline \multirow[t]{2}{*}{ Sl.no. } & \multirow{2}{*}{$\begin{array}{l}\text { Morpho-physio-biochemical } \\
\text { parameter }\end{array}$} & \multicolumn{2}{|l|}{ Control plant* } & \multicolumn{2}{|c|}{ Transformed plant** } \\
\hline & & Stressed & Unstressed & Stressed & Unstressed \\
\hline \multirow[t]{4}{*}{1} & \multicolumn{5}{|l|}{ Morphological } \\
\hline & Plant height $(\mathrm{cm})$ & $88.29 \pm 1.67$ & $88.31 \pm 1.69$ & $88.33 \pm 1.74$ & $88.32 \pm 2.01$ \\
\hline & No. of leaves & $11.20 \pm 1.30$ & $14.00 \pm 1.50$ & $13.8 \pm 1.48$ & $14.02 \pm 1.09$ \\
\hline & No. of flowers & $6.80 \pm 1.16$ & $10.60 \pm 1.01$ & $7.4 \pm 0.08$ & $10.40 \pm 0.80$ \\
\hline \multirow[t]{2}{*}{2} & \multicolumn{5}{|l|}{ Physiological } \\
\hline & RWC (\%) & $83.98 \pm 0.99$ & $81.41 \pm 0.24$ & $90.89 \pm 1.64$ & $81.52 \pm 0.20$ \\
\hline \multirow[t]{8}{*}{3} & \multicolumn{5}{|l|}{ Biochemical } \\
\hline & Photosynthetic pigment & & & & \\
\hline & Chl.a $(\mu \mathrm{g} / \mathrm{gm})$ & $138.11 \pm 0.82$ & $141.02 \pm 1.1$ & $155.13 \pm 4.3$ & $141.03 \pm 0.91$ \\
\hline & Chl.b ( $\mu \mathrm{g} / \mathrm{gm})$ & $33.19 \pm 0.62$ & $35.15 \pm 1.23$ & $46.37 \pm 0.53$ & $35.32 \pm 0.34$ \\
\hline & Chl.a+ Chl.b ( $\mu \mathrm{g} / \mathrm{gm})$ & $171.31 \pm 1.30$ & $176.17 \pm 2.1$ & $201.5 \pm 4.8$ & $176.36 \pm 1.13$ \\
\hline & Carotenoid & $101.98 \pm 0.86$ & $106.30 \pm 0.54$ & $109.78 \pm 0.45$ & $106.90 \pm 0.43$ \\
\hline & Proline content $(\mu \mathrm{g} / \mathrm{mg})$ & $107.56 \pm 1.49$ & $96.60 \pm 2.18$ & $110.83 \pm 1.61$ & $96.38 \pm 1.84$ \\
\hline & 3. Membrane stability index & $80.71 \pm 0.73$ & $82.63 \pm 0.83$ & $82.02 \pm 0.79$ & $82.92 \pm 0.85$ \\
\hline
\end{tabular}

*Observations were recorded on 4 replications each averaged over 4 plants.

** Observations were recorded on 16 independent transgenics. 


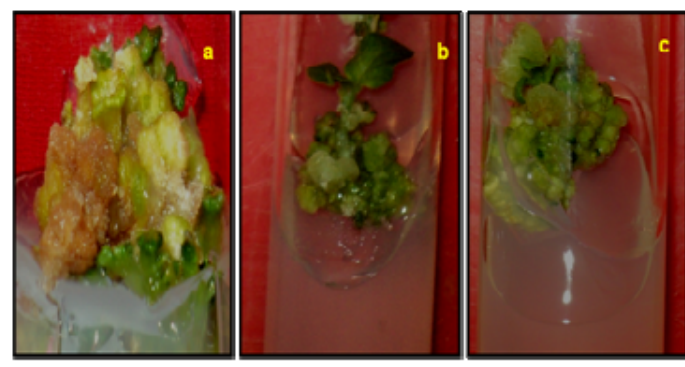

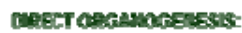

Intibuat and Afreatio

Centylabarsy luat

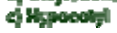

Plate 1. Direct Organogenesis
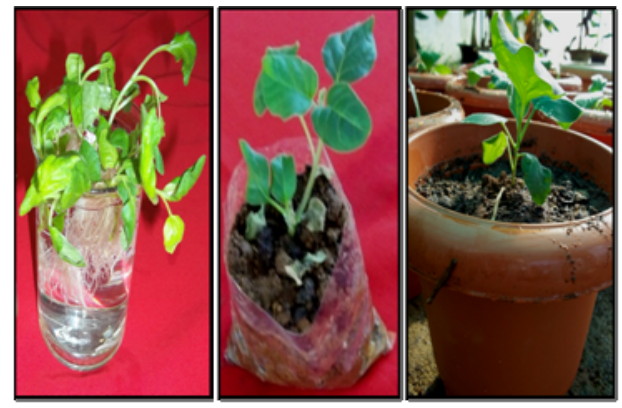

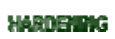

Plate 3. Acclimatization
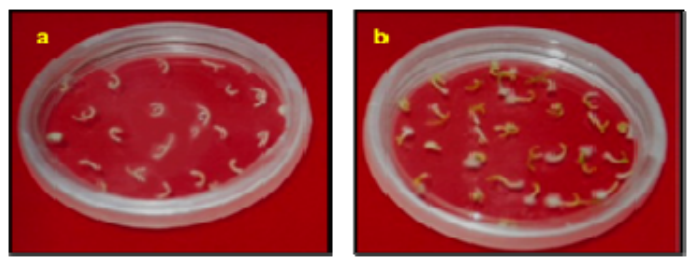

LETHAL DOBE OF CEFOTIXIME

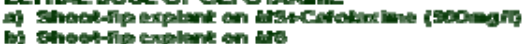

Plate 5. Lethal dose of cefotaxime

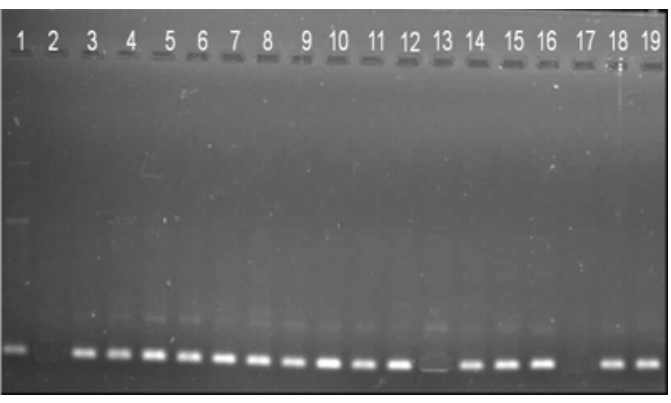

MOLECULARANALYSIS OF TRAHSFORMED PLART Land 1:- wa coitrol (plasidd CNA)

Lane 2- we control

Lane 3-19:- Putaline bransfomerits DHA IT0 1-17 glants:

Plate 7. Molecular analysis of transgene

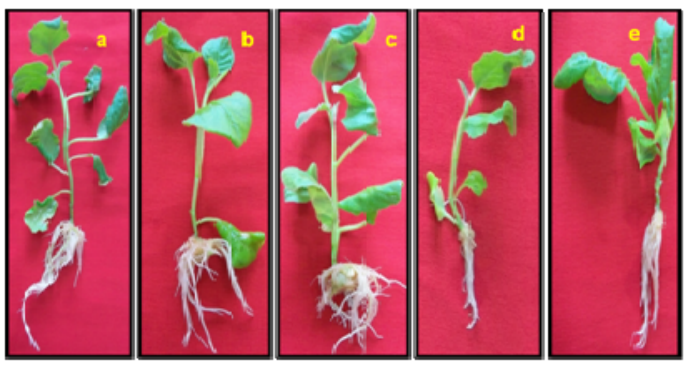

ROONMGOW JWFERENT MEDA

a) tasto.s mil MaA

b) Histocs myinad

e) Msso 1 moin WaA

d) $144 \mathrm{Ms}$ ined

Plate 2. Rooting on different media

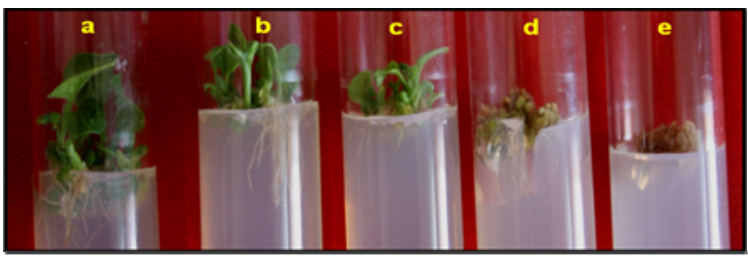

KANAMYCIN BASED SELECTION SYSTEM

MS +2 mgn sap supplimented whb different coneemtrations of Kanamyein,

a) o mgll (Control)

b) $40 \mathrm{mgh}$

c) \$o mgl

d) $\mathrm{mgn}$

e) $100 \mathrm{mg} /$

Plate 4. Kanamycin based selection system

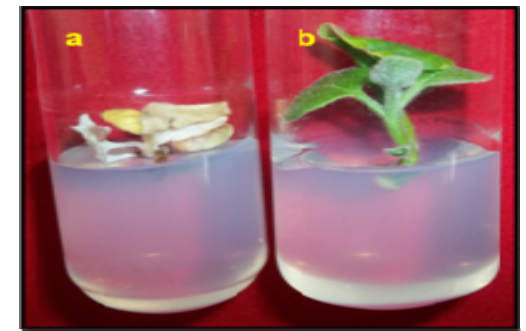

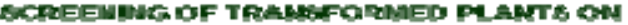

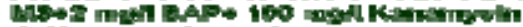
ab thobutranstormes

b) Trannfowned

Plate 6. Kanamycin based analysis of transgene

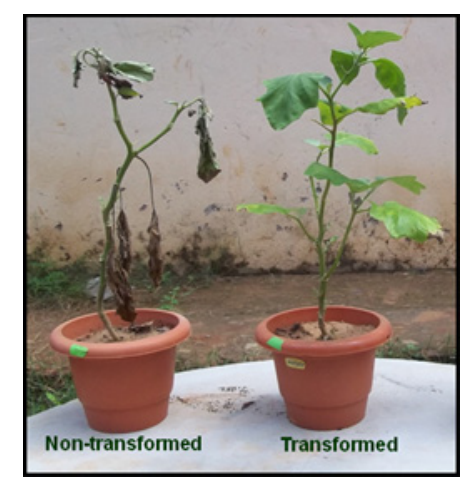

SCREENING OF TRANSFORMEO PLANTS AFTER 15 DAYS OF MOISTURE STRESS

Plate 8. Screening of transformants under stress 


\section{Discussion}

A basic requirement for a successful gene transfer system for producing transgenic plants is the availability of a target tissue made up of a large number of regenerable cells that are accessible to the gene transfer treatment and that will retain the capacity for regeneration (Birch, 1997). Brinjal, although responds well to in vitro culture system, shows genotypic variability to organogenesis (Dhavala et al., 2010). In this background, an efficient in vitro regeneration system has been developed which was used for present genetic transformation studies. The protocol adopted in the current study uses transformation of competent cells in the shoot apex of germinating seedlings through Agrobacterium mediated transformation and for plant driven regeneration. The present investigation was carried out for transformation of local cultivar of Brinjal viz., Utkal Anushree which is most popular in parts of Odisha for its high productivity but for its susceptibility to moisture stress. The crops like tobacco and rice transformed with DREB1A under the control of rd29A promoter have shown increased tolerance to abiotic stresses due to drought and cold ( Kasuga et al., 2004; Oh et al., 2005). Till now, no efforts have been made for genetic transformation in this cultivar for abiotic stress tolerance development. An attempt was made to transform the brinjal plant with $r d 29 A:: D R E B 1 A$ gene through Agrobacterium mediated transformation. The in vitro transformants obtained in this study were from the explants pre-cultured for 72 hours before co-cultivation with Agrobacterium tumefaciens. The results indicated that the explants pre-cultured were more suitable for integration of transgenes as they would provide a higher probability for transformed cells to initiate division. Liu et al. (1990) and Rama (1997) also opined that presence of actively dividing cells in the shoot apex is important for Agrobacterium-mediated transformation. The transformation frequency was 6.40 percent as revealed by PCR amplification with gene specific primers. This low frequency of transformation was probably due to problems in sampling tissues from chimeric transformants obtained through organogenesis which involves more than one cell in the shoot initiation process. Kar et al. (1996) also opined that in an organogenetic system, there is a risk of losing events of transformation due to chimera. Repeated selection in rapidly multiplying shoots is thought to eliminate untransformed tissues. Moisture stress tolerance due to possible over-expression of DREB1A gene was studied in terms of physiological and biochemical analysis such as estimation of photosynthetic pigments, proline content, membrane stability index and relative water content.

Several reports have indicated higher levels of chlorophyll content and carotenoid content in drought tolerant plants as compared to susceptible ones (Gummuluru et al., 1989) which has been reflected in the present investigation (Table 6). The physiological changes observed in the control plant under stress could be result of deleterious effects of water deficit on important metabolic pathway. Product of DREB1A gene regulates gene expression and signal transduction during the drought stress which may attribute to better responses of various defense mechanisms adapted by the transformed plant. Maintenance of membrane integrity and function under a given level of dehydration stress has been used as a measure of moisture stress tolerance by various workers (Premchandra et al., 1990). Decrease in membrane stability index reflects the extent of lipid peroxidation caused by active oxygen species (Dhindsa et al., 1981). Here in this investigation, the transformed plant showed higher membrane stability than the control plant under stress which points to the higher level of expression of DREB gene that activates some other genes related to the drought stress and therefore some transformed plants have shown better adaptation and normal growth even after 15 days of moisture stress (Plate 8). Overexpression of DREB1A under the control of CAMV35S promoter has some negative effects on plant like stunted growth which has been overcome by use of a stress inducible rd29A promoter and improvements in the stress tolerance responses of the transgenic plants and much improved growth under normal conditions were observed with the construct involving rd29A promoter (Kasuga et al., 1999; Oh et al., 2005). Here in the present investigation, the transformed plant has shown similar growth pattern as that of control plant (Table 6) as predicted. These findings suggest that the transgenic brinjal plant can be advanced for further generation and toxicology studies for clearance of biosafety issues for the release of transgenic brinjal.

\section{Acknowledgement}

We acknowledge DBT, New Delhi for providing financial assistance to M. Sc. (Ag.) Biotechnology programme.

\section{References}

Arnon, D. T. (1949). Copper enzymes in isolated chloroplast polyphenol oxidase in Beta vulgaris. Plant Physiol., $24,1-15$.

Barr, H. D., \& Weatherley, P. E. (1962). A re-examination of the relative turgidity technique for estimating water deficit in leaves. Aust. J. Biol. Sci., 15, 413-428.

Bates, L. S., Waldren, R. P., \& Teare, I. D. (1973). Rapid determination of free proline for water stress studies. Plant Soil., 39, 205-207. 
Birch, R. G. (1997). Plant transformation: Problems and strategies for practical application. Annual review of Plant Physiology and Plant Molecular Biology, 48, 297-326.

Dhavala, V. N., Chakravarthi, V., Indukuri, U., Goparaju, A., \& Venkateswrarao, Y. (2010). Effect of genotype, explant and hormonal concentration on in vitro response of Eggplant. Notulae Scientia Biologicae, 2(3), 77-85.

Dhindsa, R. S., Plumb-Dhindsa, P., \& Thorpe, T. A. (1981). Leaf senescence correlated with increased levels of membrane permeability and lipid peroxidation and decreased levels of superoxide dismutase and catalase. J. Exp. Bot., 32, 93-101.

Edwards, K. C., Johnstone, C., \& Thompson, C. (1991). A simple and rapid method for the preparation of the genomic plant DNA for PCR analysis. Nucleic Acids Research, 19, 1349.

Franklin, G., \& Lakshmisita, G. (2003). Agrobacterium tumefaciens-mediated transformation of eggplant (Solanum melongena L.) using root explants. Plant Cell Rep., 21, 549-554. http://dx.doi.org/10.1007/s00299-002-0546-9

Gummuluru, S., Hobbs, S. L. A., \& Jana, S. (1989). Physiological responses of drought tolerant and drought susceptible wheat genotypes. Photosynthetica, 2, 479-485.

Kar, S., Johnson, T. M., Nayak, P., \& Sen, S. K. (1996). Efficient transgenic plant regeneration through Agrobacterium-mediated transformation of chick-pea ( Cicer arietinum L.). Plant Cell Reports, 16, 32-37.

Kasuga, M., Setsuko, M., Shinozaki, K., \& Yamaguchi-Shinozaki, K. (2004). A Combination of the Arabidopsis DREB1A Gene and Stress-Inducible $r d 29 A$ Promoter Improved Drought- and Low-Temperature Stress Tolerance in Tobacco by Gene Transfer. Plant and Cell Physiology, 45(3), 346-350.

Kirk, J. T., \& Allen, R. L. (1965). Dependence of pigment synthesis on protein synthesis. Biochem. Biophys. Res. Commun., 21, 523-530.

Koivu, K., Valkonen, J. P., Sivamma, T., Tauzz, S. R., \& Pehu, E. (1995). Agrobacterium tumefaciens mediated transformation of Solanum brevidens and Solanum tuberosum cv. Pito. Acta Agriculturae Section B. Soil and Plant Science, 45(1), 78-87.

Liu, W., Parroti, W. A., Hildebrandt, D. F., Collins, G. B., \& Williams, E. G. (1990). Agrobacterium induced gall formation in bell pepper (Capsicum annuиm L.) and formation of shoot like structures expressing introduced genes. Plant Cell Reports, 9, 360-364.

Mohinder, K., Ajmer, S., Dhatt, J., Sandhu, S., \& Gosal, S. S. (2011). In vitro plant regeneration in brinjal from cultured seedling explants. Indian J. Hort., 68(1), 61-65.

Oh, S. J., Song, S. I., Kim, Y. S., Jang, H. J., Kim, S. Y., Kim, M., Kim, Y. K., \& Nahm, B. H. (2005). Arabidopsis $\mathrm{CBF}$ /DREB1A and ABF3 in transgenic rice increased tolerance to abiotic stress without stunting growth. Plant Physiol.

Onwueme, I. C. (1979). Rapid plant conserving estimation of heat tolerance in plants. J. Plant Physiol., 27, $264-270$

Prabhavathi, V., Yadav, J. S., Kumar, P. A., \& Rajam, M. V. (2002). Abiotic stress tolerance in transgenic eggplant (Solanum melongena L.) by introduction of bacterial mannitol phosphodehydrogenase gene. Molecular Breeding, 9, 137-147. (C) 2002 Kluwer Academic Publishers. Printed in the Netherlands.

Premchandra, G. S., Saneoka, H., \& Ogata, S. (1990). Cell membrane stability an indicator of drought tolerance as affected by applied nitrogen in soyabean. J. Agric. Sci. (Camb), 115, 63-66.

Rama, N. (1997). Standardization of protocols for Agrobacterium mediated gene transfer in Chilli (Capsicum annum L.). M.Sc. (Agril.) thesis University of Agril. Sciences, Bangalore.

Sambrook, J., \& Russell, D. W. (2001). Molecular Cloning, A Laboratory Manual, $3^{\text {rd }}$ edn. Cold Spring Harbor Laboratory Press, Cold Spring Harbor, NY.

Shamina, A., Sharmin, A., Humayan, K., Abul, M., Kanak, K. S., \& Mohammad, F. A. (2008). In Vitro Propagation of Eggplant through Meristem Culture. Agric. Conspec. Sci., 73(3).

Yamaguchi-Shinozaki, K., \& Shinozaki, K. (1993). Arabidopsis DNA Encoding Two Desiccation-Responsive rd29 Genes. Plant Physiol., 101, 1119-1120. 